\title{
MORPHOLOGICAL AND ECOLOGICAL STUDY OF PHYSODERMA DULICHII ${ }^{1}$
}

\author{
ROBERT M. JOHNS ${ }^{2}$ \\ Department of Botany, University of Michigan, Ann Arbor, Michigan
}

\begin{abstract}
A B S T R A C T
A new species of aquatic Phycomycete, Physoderma dulichii Johns, parasitic on the aquatic sedge Dulichium arundinaceum (L.) Britt., is described from northern Michigan. This parasite infects and kills the upper epidermal cells of the host leaves. Macroscopically, infection by $P$. dulichii is indicated by striking brown bands with irregular margins, at intervals on the upper surfaces of the leaves. Like other species of Physoderma, this organism's development includes two distinct phases, an epibiotic monocentric phase producing asexual zoospores and an endobiotic polycentric phase bearing thick-walled resting spores that germinate after an extensive period of maturation at low temperature to form zoospores. The morphology and development of the two phases and of resting spore germination are reported in detail. Only the immature leaves of the host are susceptible to infection, which may be initiated by the introduction of mature resting spores, zoospores from germinated resting spores, or zoospores from epibiotic sporangia. Resting-spore zoospores may also produce the endobiotic stage directly. Initiation of infection in nature requires that the terminal cluster of immature leaves on the host plant be submerged, but infection of subsequently formed leaves of emergent culms can be accomplished through the agency of zoospores from epibiotic sporangia on older leaves. The relation of infected stands of hosts to their environment is discussed and the importance of standing water to infection noted. The geographical distribution of the parasite shows correlation with the drainage basins of the Great Lakes, the St. Lawrence River, and the northern Atlantic Coastal Plain
\end{abstract}

IN A previous publication (1957) a brief account and technical description were given of a new species of Physoderma parasitic on Dulichium arundinaceum (L.) Britt. It was unique in being confined to the upper epidermal cells of the host and being the only phycomycete then known parasitic on the peculiar sedge Dulichium. Other characters which will be described add to its distinctiveness.

All well-known species of Physoderma form two distinct and separate thalli. One, the epibiotic stage, is a single sessile, external, thin-walled zoosporangium with a rhizoidal system inside a single host cell. The other, endobiotic stage, is entirely within the host and consists of an extensive delicate rhizoidal system on which are septate enlargements termed turbinate organs. These rhizoids wander from cell to cell extending the infected area. Relatively enormous resting spores with dark thick walls form as outgrowths from the turbinate organs and produce a macroscopic lesion of the host. These spores overwinter and germinate to form posteriorly uniflagellate

${ }^{1}$ Received for publication February 24, 1965.

Contribution from the Botany Department No. 1166 and from the Biological Station, University of Michigan. Aided in part by a National Science Foundation grant under the direction of F. K. Sparrow.

${ }_{2}^{2}$ Deceased, 1963. I have attempted to put the major part of the author's material on this Physoderma based upon his dissertation for the Ph.D. degree in shape for publication. Fig. 1-10 and $11-28$ are said to be the same magnification, $\times 1000$, which seems doubtful. Probably 1-11 are approximately $\times 500$ and $12-28 \times 1000$. F. K. S. swarmers which infect the host in the early growing season. The relation of the two phases to one another is not well understood.

Symptoms AND EFFECTS ON THE Host -One of the most singular effects of Physoderma dulichii is that each succeeding leaf on a single host stem tends to bear brown infection spots or bands in the same relative position (Fig. A). This pattern is understandable in light of the orientation of young leaves, the position where infection occurs and the ability of epibiotic sporangial zoospores to produce new infections. The terminal cluster of young leaves is vertically oriented and strongly keeled, and each of them interlaps with a succeeding one. They do not become flattened and oriented more or less perpendicular to the stem axis until after the internode above their point of insertion has elongated. Within the leaf cluster infection is limited to fairly discrete areas. This appears to result from the drops of water necessary for germination and for the dispersal of the infecting zoospores being trapped at these positions in the leaf cluster. Such drops, though not in contact with a very great portion of a single leaf, are, however, in contact with corresponding areas of several leaves because successive leaves overlap. Thus it is possible for a single focus of inoculum to result in the infection of similar portions of several leaves. Epibiotic zoospores subsequently infect areas of later-formed leaves. Elongation of the internodes between these leaves results in their separation in a characteristic patterned arrange- 


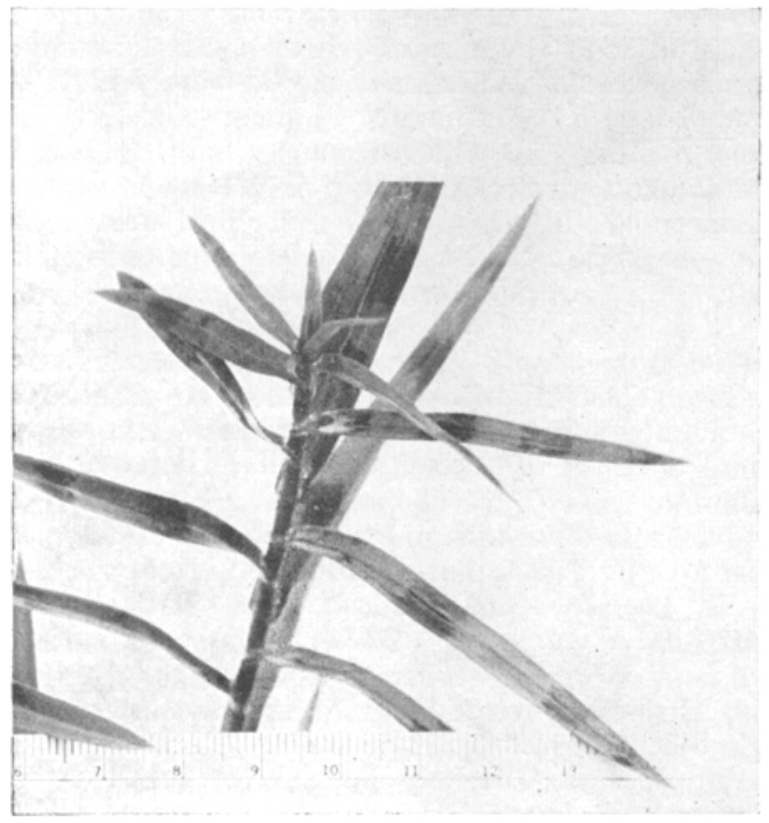

Fig. A. Leaves of Dulichium showing banding on upper cpidermis caused by Physoderma.

ment with each succeeding leaf bearing brown infected areas in the same relative positions.

The brown bands of discoloration with indefinite margins on the upper epidermis are the only macroscopic symptoms. There is no evidence of cellular hypertrophy or lack of vigor. Infected plants flower and set fruit in a normal fashion. If the aforementioned brown pigments mask the light, this results in no apparent debility of the host.

Only the infected upper epidermal cells are affected by the fungus; adjacent epidermal and mesophyll cells are normal. Epibiotic sporangia always produce in such epidermal cells a callus ring around the penetration tube, and the cells are eventually killed. There is an accumulation here of the brownish substance which produces the characteristic color of the infected areas. No other effect is evident; it is apparent that $P$. dulichii has achieved a state of balanced parasitism which causes little inconvenience and no serious damage to its host.

MoRPhology AND DEVELOPMENT-The resting spore--Resting spores (Fig. 1) occur only in the upper epidermal leaf cells of the host. When they develop singly, they are ovoid to almost spherical. Usually 1-3 (up to 6) develop in a single cell, in which case they are somewhat angular due to mutual compression.

There is a marked variability in resting spore size as indicated by a range of 14-39 $\times 25-59.7 \mu$. The mature spore wall consists of a single layer which is approximately $1.2 \mu$ in thickness and light brown. The contents consist of a large, central vacuole and a peripheral layer of refractive globules $2-3.5 \mu$ in diameter which are uniformly distributed throughout the cytoplasm. Tests with Sudan IV and with osmic acid solution indicate that these peripheral structures are lipoidal in nature.

Dichotomously branched "haustoria" are found on immature spores (Fig. 27, 28) but cannot be demonstrated on them at maturity (Fig. 2). Wall pits, which in certain other species mark the positions where haustoria formerly emerged, cannot be observed even after clearing with chloral hydrate or sodium hypochlorite, or after boiling in potassium hydroxide solution. Furthermore, no circular line of wall dehiscence typical of many other species of the genus is observable.

Brown, opaque, host material, together with fragments of cell wall, tend to remain associated with the resting spores following release from decayed host leaves. These obscure details of resting spore structure and the process of germination.

The first success in inducing germination of the resting spores was obtained in April, 1957, using collections from October, 1956, which had been kept moist during the intervening six months while held at $8 \mathrm{C}$. Subsequently, germination was obtained without difficulty during 1957 from collections made in August, 1956, and in March, 1957, as well as from October, 1957 collections. Conditions under which germination occurred had previously been employed repeatedly and without success on various lots of spores. This strongly suggests that a prolonged period of maturation is necessary before they will germinate. Conditions under which the resting spores are maintained prior to germination are also important. All collections which were kept moist or wet and at temperatures of $8 \mathrm{C}$ or lower germinated; those which were dried at room temperature did not. In an attempt to discover whether this lack of viability was due to moisture or temperature, a collection of spores known to be viable was dried one week over calcium chloride at $8 \mathrm{C}$. These spores failed to germinate. Attempts to maintain collections of viable spores moist or wet at room temperature resulted in rapid and thorough decomposition of the collections, from which viable spores could not be recovered.

Germination was initiated $60-72 \mathrm{hr}$ after resting spores were placed in tap or bog water. Zoospores may be observed after about $72 \mathrm{hr}$, and germination continues for 6 days or more following incubation. A germination of $1-2 \%$ indicates that the basic factors influencing this process are not yet known.

The first evidence of germination is an increase in size of the spore contents, presumably due to the absorption of water (Fig. 3). This distends the walls of the host cell which frequently remain intact around the spores. Concomitantly, the peripheral refractive globules become more or less evenly dispersed throughout the spore contents, as the large central vacuole disappears (Fig. 3). These initial changes occupy $4-6 \mathrm{hr}$. 


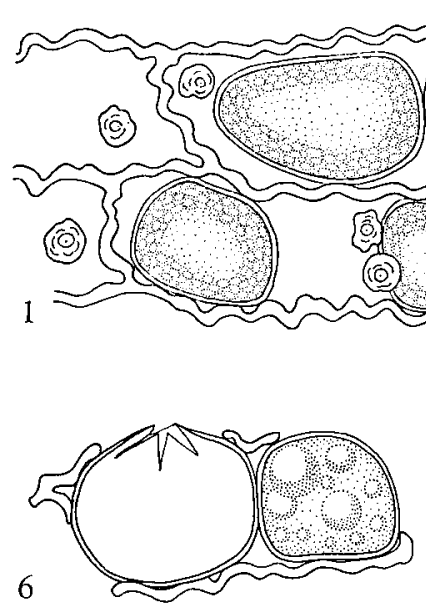

6<smiles>C=CC1CCCCCCCC1=O</smiles>

13
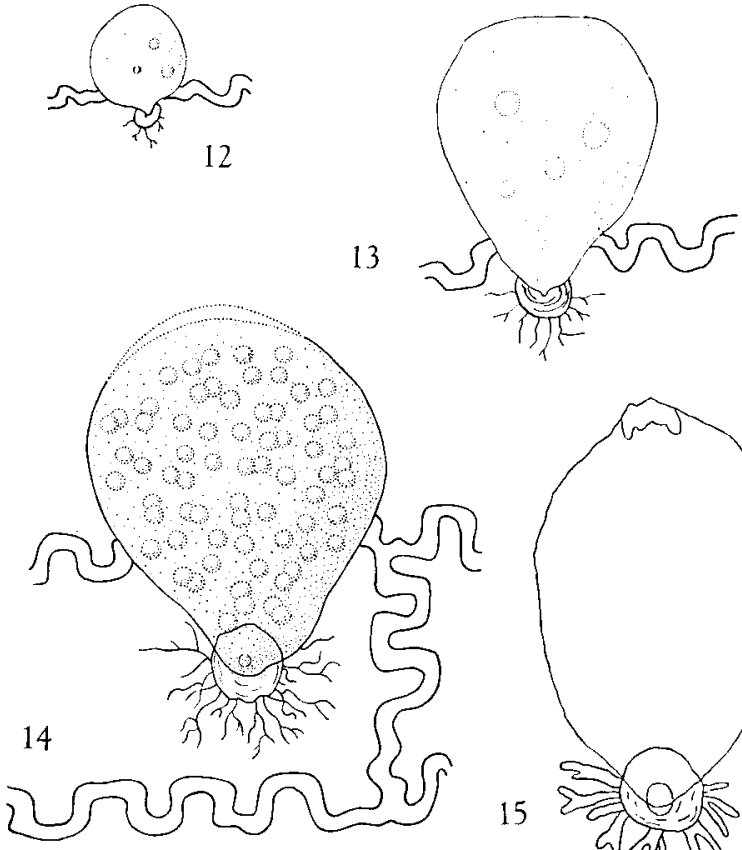

15

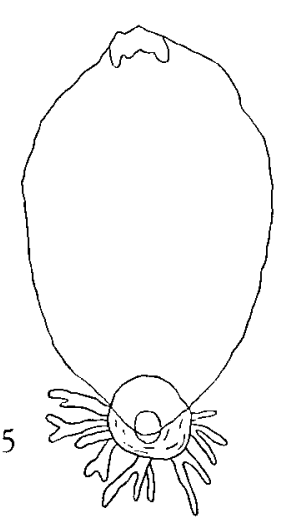

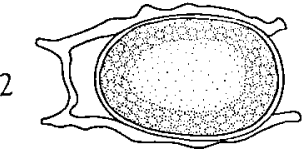

3
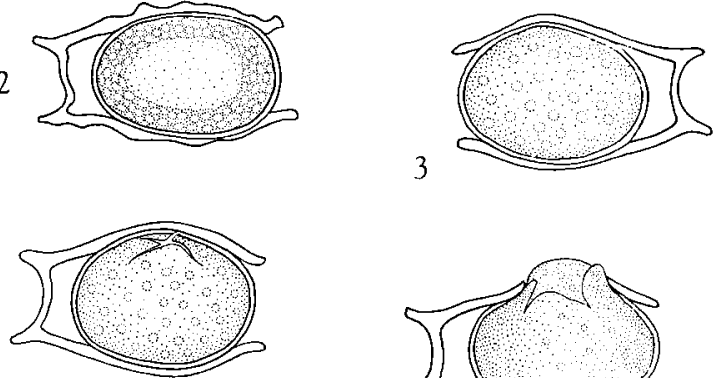

4

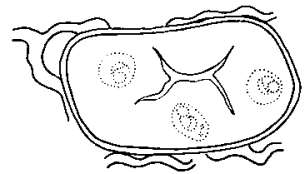

7

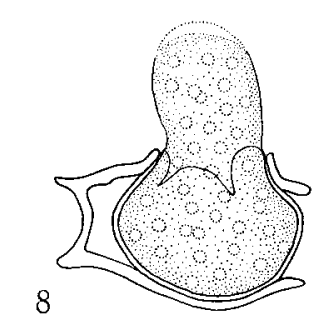

5

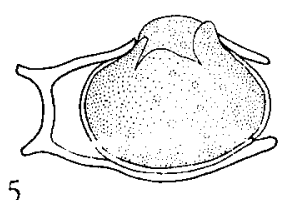

9
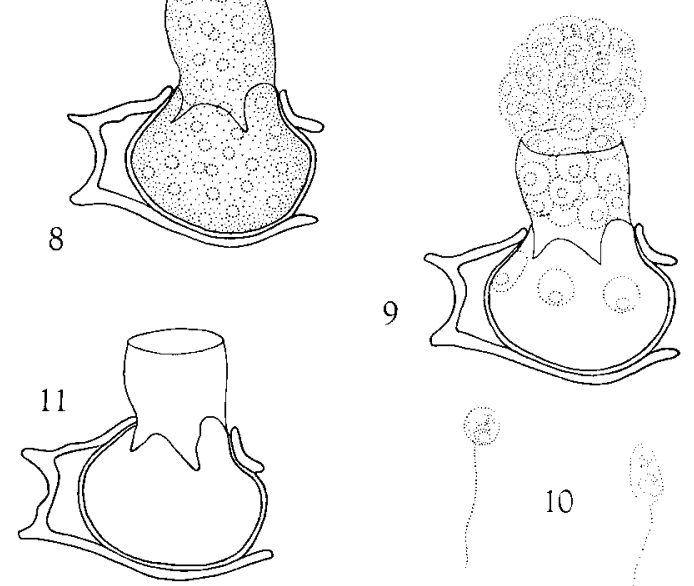

10

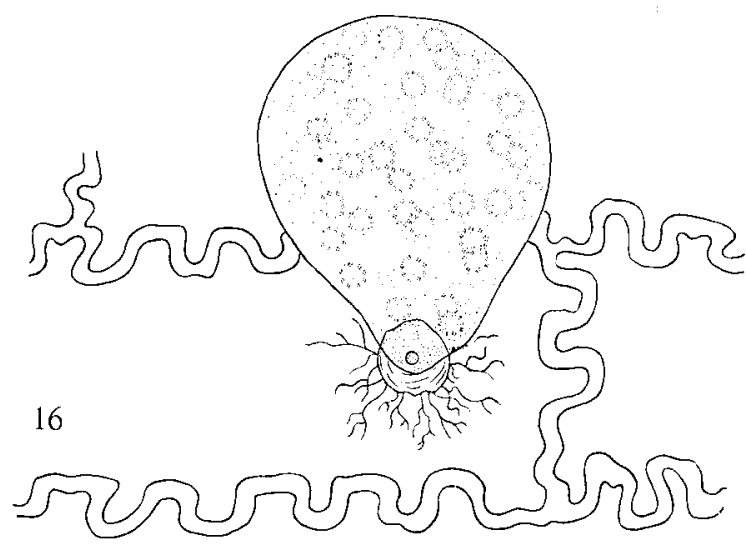

Fig. 1-16. Indo- and epibiotic stages of Physoderma dulichii on Dulichium.-Fig. 1. Mature resting spores within the epidermal cells of Dulichium. Several rings of callus formed by epibiotic phase are present.-Fig. 2. Single mature resting spore.-Fig. 3. Single resting spore in the first stage of germination. The spore has become swollen and the oil droplets are dispersed throughout its interior.-Fig. 4. The wall of the spore has fractured, and its contents have become evenly granular, with minute dispersed refractive granules.-Fig. 5. Emergence of the endosporangium.-Fig. 6. Discharged resting spore and one in which the content has lost its characteristic organization. Such spores were never observed to germinate. - Fig. 7. Discharged resting spore showing the irregularly stellate appearance of the fractured wall and containing threc zoospores.-Fig. 8. Mature endosporangium containing the refractive globules of the zoospores. At the apex a gelatinous clear area has developed which will dissolve to form the discharge pore.-Fig. 9. Discharge of the zoospores, which are momentarily motionless at the papillar opening.-Fig. 10. Zoospores, each containing a bright refractive globule, a nuclear cap and several smaller refractive granules.-Fig. 11. Resting spore following discharge, the empty endosporangium is still evident.-Fig. 12. A young epibiotic thallus. Development of the callus ring in the host coll wall is already evident.-Fig. 13. Somewhat later stage in sporangial formation.-Fig. 14. Mature epibiotic sporangium with a broad apical papilla and containing the refractive globules of the zoospores.-Fig. 15. Empty sporangium.-Fig. 16. Epibiotic sporangium of mature size. Bright refractive granules outline spherical areas which appear to be th? sites of zoospore formation. 
Opening of the resting spore is presaged by the appearance of irregular fractures in its wall (Fig. 4). These enlarge and eventually coalesce to form an irregular opening. Meanwhile the spore contents continue to increase in volume, and in the course of $3 \mathrm{hr}$ these bulge through the opening in the spore wall (Fig. 5) as a steadily elongating finger-like protrusion. The refractive globules in the contents break up into minute, uniformly distributed particles.

The endosporangium (Fig. 8) thus formed is somewhat pyriform in shape with its basal portion contained within the wall of the resting spore and its external cylindrical part up to $22 \mu$ long terminated by a rounded apex. The contents remain homogeneous and unchanged for $1 \frac{1}{2}-2 \mathrm{hr}$. Subsequently, within a period of $20 \mathrm{~min}$ a broad area at the apex becomes differentiated as a discharge papilla $11-14.2 \mu$ in diameter, and the refractive globules of the zoospores are formed by the coalescence of minute refractive particles in the cytoplasm. The endosporangia are apparently mature and ready for zoospore discharge. Eight to $12 \mathrm{hr}$ may intervene between this apparent maturation and actual discharge of the zoospores. The first evidence of impending discharge is a slight swelling of the apical papilla, as a result of which its outer limit becomes indistinct. The greater part of the contents of the endosporangium is then forcibly and abruptly discharged (Fig. 9), forming a compact, spherical, seemingly naked mass outside the discharge pore. The zoospores are fully mature but without individual motion upon discharge, and their characteristic morphology is first apparent at this time. Two to $5 \mathrm{~min}$ after discharge, the individuals begin to move, at first slowly within the confines of the mass, then more actively, and finally they pull away from the region of the sporangium. Following their dispersal, those which remain in the endosporangium assume motility and move out separately through the discharge pore by their own flagellar activity. Empty resting spores show a well-defined series of cracks (Fig. $6,7,11)$.

The exact number of zoospores produced by endosporangia is difficult to determine. There appear to be $30-40$, but there is some variation which is probably correlated with the size of the resting spore itself.

Resting-spore zoospores (Fig. 10) are spherical, $5.5-6.2 \mu$ in diameter and bear a posteriorly directed flagellum approximately $25 \mu$ long. Internally each body contains a conspicuous, refractive, posterior, somewhat eccentric globule $2.0-2.7 \mu$ in diameter and two to four minute lateral refractive droplets. A crescent-shaped nuclear cap is also evident. After fixation of the spore in osmic acid vapor and staining with aqueous crystal violet the cap is seen to cover the anterior portion of the nucleus. Movement of a zoospore is even, rapid, and at room temperature continues for at least $5 \mathrm{hr}$.

The epibiotic phase-Early infection stages (Fig.
12) may be observed 2 days following inoculation of young leaves on living host plants with either germinating resting spores or with zoospores from the endosporangia. In the youngest stages seen, the encysted zoospore had already produced a penetration tube which had grown through the wall of the host epidermal cell and produced at its tip a tuft of much-branched rhizoids, $12.4-18.6 \mu$ in extent. Entrance of the germ tube of the zoospore stimulates the inner cell wall of the host to form an interior ring of callus, $3.4-5.5 \mu$ in diameter (Fig. 12). This striking, persistent structure, which encircles the penetration tube, is like the cell wall in texture, and tests indicate that it contains cellulose.

The epibiotic cyst of the young thallus is at first spherical and of the same size as the zoospore from which it was derived; it contains a single bright refractive globule. The cyst soon expands, losing its spherical shape and becoming obovoid to obpyriform (Fig. 12, 13). The symmetry of the sporangium is interrupted by the presence of an inconspicuous knob near its base which appears to represent an unexpanded portion of the wall of the encysted zoospore. During enlargement, a number of refractive globules of varying size are formed and become scattered through the finely granular cytoplasm. As the sporangium approaches mature size, the refractive globules break up and disperse, re-forming as minute, glistening droplets. These aggregate so that they outline spherical areas approximately $3 \mu$ in diameter which are evenly spaced throughout the sporangial cytoplasm (Fig. 16). They appear to function as centers of zoospore formation. Thirty minutes later the characteristic globules of the zoospores have been formed by coalescence of refractive particles in the cytoplasm (Fig. 14), and coincidently there is formed a broad apical or subapical discharge papilla $9.5-12 \mu$ in diameter. There is no visible evidence at this time of cytoplasmic cleavage delimiting the zoospores, and following formation of the papilla and the spore globules, the sporangium is mature and is ready for discharge. Both mature and discharged epibiotic sporangia have been observed as early as $41 / 2$ days following inoculation of living plants of Dulichium with zoospores from endosporangia.

At maturity (Fig. 14) the epibiotic sporangia are obovoid to obpyriform, $18.8-29.9 \times 36.1-48.7 \mu$, and their long axes, rather than being perpendicular to the host epidermis, usually form angles of approximately $60^{\circ}$ with it.

Discharge of the epibiotic sporangium resembles in many respects that previously described for the endosporangia (Fig. 17). Deliquescence of the papilla is followed by the forcible expulsion of the majority of the fully formed zoospores which exhibit their characteristic internal structure upon emergence. They at first form a quiescent, spherical mass at the sporangial apex for several minutes before individually becoming motile and swimming away. Any remaining spores swim successively out through a discharge pore. 
After discharge it becomes evident that a spherical portion of the sporangial cytoplasm, 6-8.5 $\mu$ in diameter, has not entered into zoospore formation (Fig. 18, 20). This lies in the base of the sporangium above the stalk of the rhizoidal system. Its cytoplasm appears finely granular and includes one to several bright refractive globules. This structure, which may be called an "endoapophysis," develops into a secondary epibiotic sporangium within the walls of the discharged primary one. Although epibiotic thalli have been observed that were three times proliferative (Fig. 21 ), once proliferative ones were most frequent and non-proliferative ones (Fig. 15) rare.

Each epibiotic sporangium may produce approximately $30-60$ zoospores which resemble those from the endosporangia in their gross morphology (Fig. 19 , freehand). They are spherical, $4.8-5.5 \mu$ in diameter, to somewhat ovoid, 3.4-4.1 $\times 7.6-8.3 \mu$, with a posteriorly directed flagellum that is $27.5-31.7 \mu$ in length. Internally, each contains a hyaline refractive globule 2.0-2.8 $\mu$ in diameter, a lunate nuclear cap, and two to four minute refractive granules. The swimming movement of the zoospores is smooth and quite rapid.

The fate of the zoospores from the epibiotic sporangia has not been disclosed by direct microscopic observation. Data from inoculation studies show them capable of producing either new epibiotic sporangia or the endobiotic phase of the organism.

The endobiotic phase-The endobiotic thallus may first be observed about 6 days following inoculation of host plants with germinating resting spores and develops as follows. After encystment of a spore on an epidermal cell, a germination tube is formed; it penetrates the host cell wall and produces at its tip a spherical to ovoid structure, the primary turbinate cell (Fig. 25a). The partially collapsed wall of the persistent empty spore has been observed on several occasions. As the primary turbinate cell increases in size, refractive granules are formed within it and one to three cross-walls laid down in no fixed pattern divide it into two to four segments (Fig. 23). The first is usually at right angles to the longer axis of the turbinate cell, but it may be oblique. Subsequent segments are in various planes without relationship to the firstformed one. Mature turbinate cells are somewhat ovoid in shape, $6.2-9.6 \times 8.2-12.4 \mu$, and bear bright refractive granules of varying size.

Each of the segments of a turbinate cell may proliferate new turbinate cells (Fig. 22, 23) as follows. From the peripheral area of a segment there is produced a delicate, thread-like outgrowth $30 \mu$ or more in length which frequently penetrates the walls of the host to infect adjacent epidermal cells. The tip of this outgrowth eventually begins to expand, and the entire contents of the segment move into the terminal swelling to produce a secondary turbinate cell. As a result, the entire contents of the turbinate organs may be lost. Repetition of this developmental sequence results in the formation of an extensive branched vegetative thallus ramifying through a number of host epidermal cells.

Resting spore formation begins first near the point of infection, in cells most crowded with the fungus. This suggests that depletion of available food-or, possibly, death of the host cell-may initiate spore production. They are usually formed like the secondary turbinate cells (Fig. 24). An outgrowth from a segment of a turbinate cell produces a terminal swelling into which the protoplasmic contents of the segment migrate. Such swellings differ from turbinate cells in having an apical ring of stubby digitations which develop into the dichotomously branched appendages on the immature spore. Resting spores may also be formed from the distal segment of a turbinate cell (Fig. 26a). Here, too, a ring of dichotomously branched appendages is produced early. Proximal segments of these turbinate cells are able to produce resting spores and other turbinate cells in the usual manner. Rarely, the primary turbinate cell may be converted directly into a resting spore (Fig. 25b).

Wherever resting spore formation is initiated, their subsequent development is the same. The young rudiments increase in size, remaining spherical to somewhat ovoid in shape as long as the available space permits this symmetry. Meanwhile, the haustorial appendages increase in length to $7-11 \mu$ (Fig. 26 a, 28) and each of them branches two or three times. At this point the spore initials have reached approximately one-half their mature size. Internally they contain evenly granular cytoplasm through which are scattered refractive granules. The enlarging spore may encounter obstacles such as the walls of the host cell and other resting spores which result in a somewhat irregular shape. The glistening granules in the cytoplasm break up to form guttulae, $2.0-3.5 \mu$ in diameter, which become uniformly distributed around the internal periphery of the spore and a large central vacuole which meanwhile has been formed (Fig. 27). At the same time the wall thickens (ca. 1.2 $\mu$ ), and becomes light brown. As earlier indicated, after maturation the haustorial appendages cannot be demonstrated either in situ or on spores freed from host tissue, nor are pits found.

Although the polycentric nature of the endobiotic thallus of $P$. dulichii might appear capable of indefinite development, it is actually determinate and rather limited in growth. Within about 5 weeks of inoculation it has nearly disappeared and only resting spores can be demonstrated. (Fig. 1).

As a result of this study, data on such features as resting spore germination, endosporangial discharge, zoospore, are presented which were not available when the fungus was first described. An amplified description is therefore provided. 

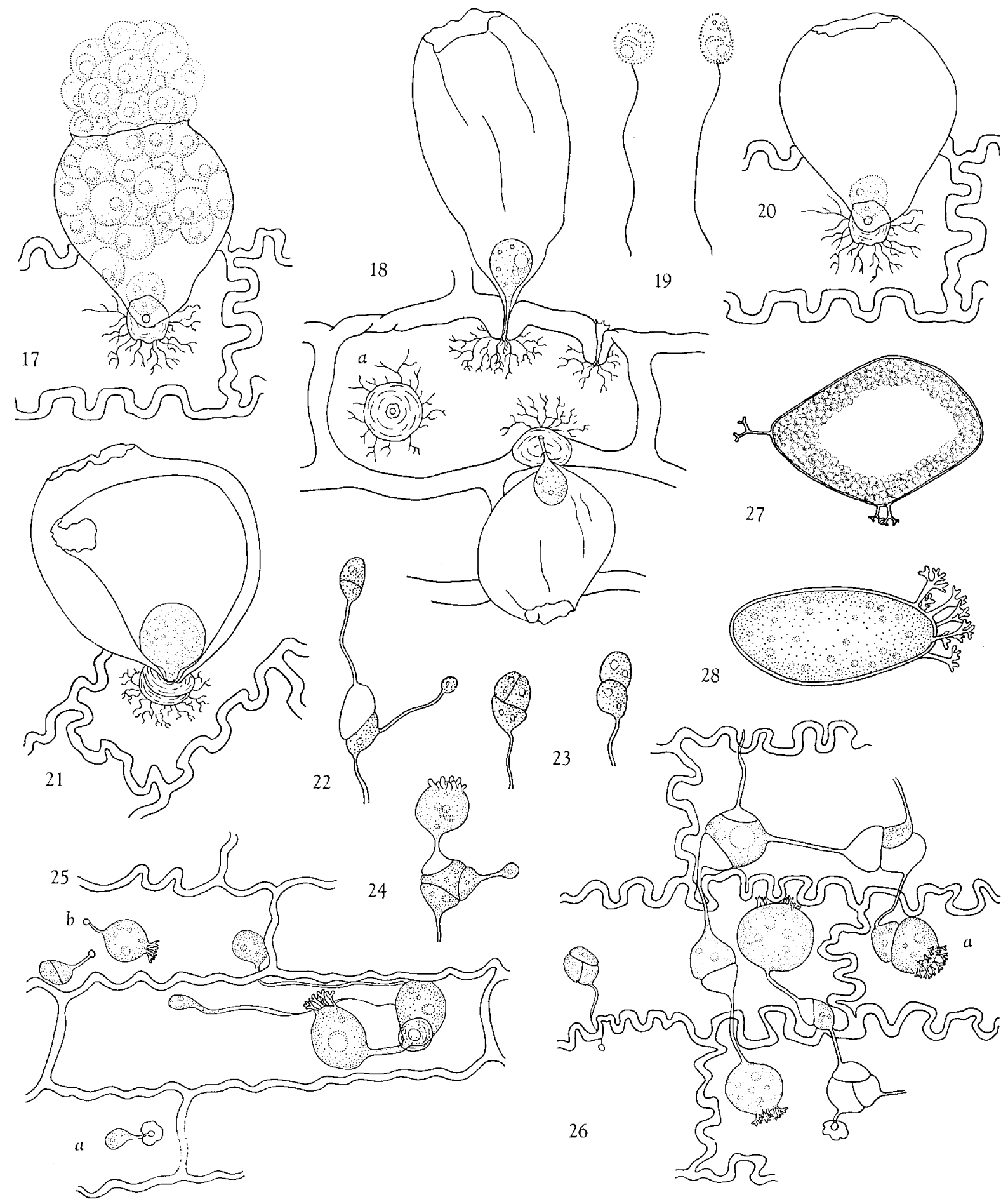

19
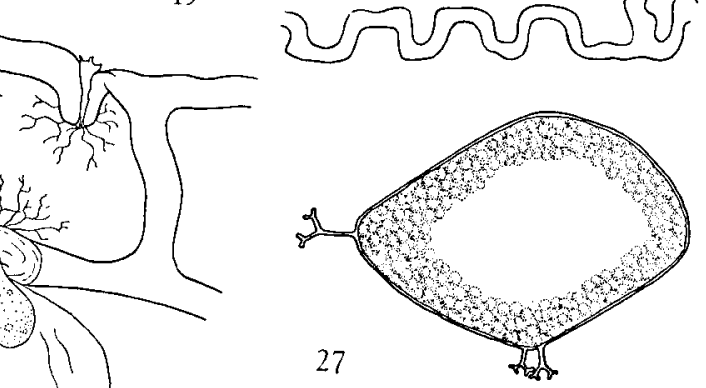

28

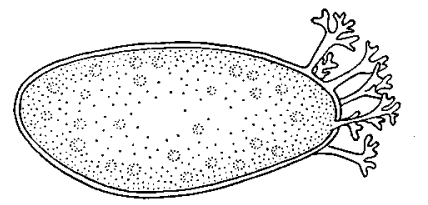

23

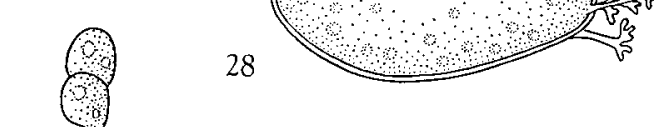

की

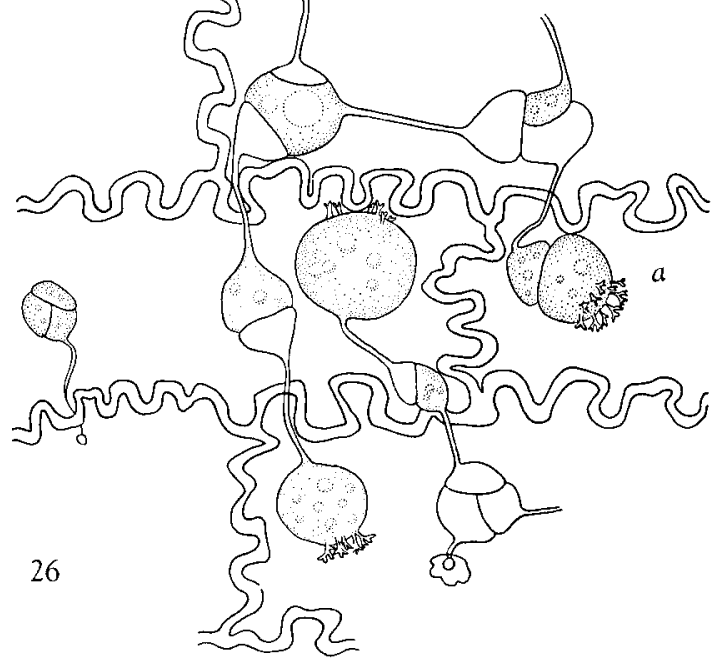

Fig. 17-28. Physoderma dulichii.-Fig. 17. Zoosporangial discharge. The endoapophysis is evident at the base of the sporangium.-Fig. 18. Two discharged sporangia with endoapophyses and two callus rings with rhizoids of sporangia that have been lost.-Fig. 19. Zoospores. The nuclear cap, bright refractive globule, and smaller accessory granules are evident.-Fig. 20. Appearance of the sporangium following discharge.-Fig. 21. Proliferative epibiotic thallus consisting of two discharged sporangia within which a third is developing.-Fig. 22. A turbinate cell in which the terminal segment has produced a secondary turbinate cell. The outgrowth from the basal segment may produce either a turbinate cell or a resting spore.-Fig. 23. Turbinate cells with 2-3 segments.-Fig. 24. Turbinate organ with four segments, one of which is giving rise to a resting spore.-Fig. 25. Habit of young endobiotic thalli within the host. At "a" a primary turbinate cell is attached to what appears to be a collapsed zoospore cyst. At "b" is a turbinate cell of two segments and another which appears to have been transferred directly into a resting spore.-Fig. 26. Habit of the endobiotic phase within the host. Three young resting spores (one at "a") with clusters of dichotomously branched appendages present.-Fig. 27. Almost mature very large resting spore in which the peripheral oil globules and central vacuole are apparent. Appendages are usually difficult to demonstrate at this stage.-Fig. 28. Large immature resting spore with its cluster of appendages. All figures $\times 1,000$. 
Physoderma dulichii Johns, Mycologia 49: 298. 1957.

Epibiotic sporangia at first spherical, subsequently obovoid to obpyriform, $18.8-29.9 \times 36.1-48.7 \mu$, their long axes forming an angle of about $60^{\circ}$ with the host epidermis, as many as four produced successively from a single thallus by internal proliferation; endobiotic system penetrating immature upper epidermal leaf cells of the host to form a bushy tuft of delicate rhizoids 12.4-18.6 $\mu$ in extent, stimulating formation internally by the host of a persistent ring of callus $3.4-5.5 \mu$ in diameter at the point of penetration of the cell wall; zoospores spherical, 4.8$5.5 \mu$ in diameter, to somewhat ovoid, 3.4-4.1 $\times 7.6-8.3 \mu$, with a postcriorly directed flagellum $27.5-31.7 \mu$ in length, and a prominent eccentric oil globule $2.0-2.8 \mu$ in diameter: at maturity discharged from the sporangium upon the deliquescence of a broad apical papilla $9.5-12 \mu$ in diameter. Endobiotic mycelium tenuous, delicate, extending through several cells of the upper epidermis of the leaves, bearing numerous 1 - to 3 -septate turbinate colls, 6.2-9.6 $\times 8.2-12.4 \mu$, whose segments give rise either to additional turbinate cells by means of threadlike outgrowths or to resting spores. Resting spores formed either from nonseptate outgrowths of turbinate cells or, occasionally by enlargement of a segment of a turbinate cell; one to four in each host cell; with thick amber wall, uniformly placed peripheral guttulae, and a large central vacuole; spherical to ovoid or somewhat irregular in shape due to mutual compression and confinement by the host cell wall, 14.1-39.2 $\times 25.1-59.7 \mu$ : bearing several clusters of dichotomously branched appendages $7.8-11.0 \mu$ in length which are lost at maturity. Resting spore germination inoperculate, by means of an irregular fracture of the spore wall, the broad apex of the subsequently formed endosporangium protruding through this opening; zoospores spherical, 5.5-6.2 $\mu$, with a prominent colorless eccentric oil globule 2.0-2.7 $\mu$ in diameter, a conspicuous nuclear cap, and a posterior flagellum, discharged following the deliquescence of a broad papilla, 11.1-14.2 $\mu$ in diameter, at the apex of the endosporangium.

Parasitic on the leaves of Dulichium arundinaceum (L.) Britt., causing irregular banded areas of brownish discoloration on the upper surface; Smith's Bog, Cheboygan County, Michigan, June 30, 1956 (Type collection); indigenous to the watersheds of the Great Lakes and the St. Lawrence River and to the northern Atlantic Coastal Plain in eastern North America.

Distinction from other species of Physoderma Until our knowledge of this group of organisms is more complete, erection of new species of Physoderma must, of necessity, be based on circumstantial evidence, and until critical crossinoculation experiments are performed host range and specificity will remain in doubt. The possibilities that a given species may evoke different symptoms in one host organism from that produced in another and that different hosts may cause variations in fungal morphology cannot be ignored. Species separation must currently depend on a complex of those characteristics which may eventually prove to be of taxonomic value.

Physoderma dulichii is the only known member of the genus, and indeed of the Phycomycetes, which occurs on Dulichium. Two other species are known to occur on members of the Cyperaceae, $P$. heleocharidis (Fuckel) Schroeter (1886) on Eleocharis palustris and $P$. schroeteri Krieger (1896) on Scirpus maritimus, and S. supinus. Both species are known only from resting spore mor- phology and symptoms evoked in the hosts. ${ }^{3}$ Examination of collections of these species from the Herbarium of the University of Michigan and from the Chicago Natural History Museum, which corroborated the published descriptions, showed that resting spore size in Physoderma dulichii $(14.1-39.2 \times 25.1-59.7 \mu)$ was significantly larger and had a much greater range than that of either $P$. heleocharidis $(13-1.9 \times 18-28 \mu)$ or $P$. schroeteri $(23-36 \mu)$. Further, the two latter species had resting spores which were hemispherical in shape, and Jones and Drechsler (1920) indicated that the presence of opercula on cleared resting spores could be determined with "moderate certainty." Such are not known in $P$. dulichii. Other distinctions from $P$. dulichii are their occurrence in the subepidermal parenchyma of the hosts rather than epidermis, and the black spots and flecks, not broad bands of discoloration, which are the characteristic host symptoms.

There is additional evidence that Physoderma dulichii is not identical with $P$. heleocharidis. The latter species occurs on Eleocharis palustris, which is found with some frequency in Smith's Bog in the midst of heavily infected populations of Dulichium. Repeated examination of $E$. pahustris from this site has failed to reveal infection. Furthermore, data from preliminary inoculation studies support the view that the E. palustris in Smith's Bog is not susceptible to $P$. dulichii.

Finally, the obovoid to obpyriform epibiotic sporangia of $P$. dulichii are morphologica'ly unique among those species of the genus in which this phase of the organism is known. ${ }^{4}$

On the basis of these known data, Physoderma dulichii appears to be distinct from previously described species of the genus.

Host-Parasite relationships-Field observations and examination of collections indicate that only the upper surfaces of the immature expanding leaves of Dulichium are susceptible to infection. It is in such material that the epibiotic phase and younger stages of the endobiotic system can be observed. In fully expanded leaves only resting spores are formed. Successful germination of the resting spores permitted a series of inoculation studies in the greenhouse which corroborated these and other field observations.

Clones of uninfected Dulichium transplanted from Smith's Bog and grown in glazed earthenware crocks in a small greenhouse under conditions of high humidity ${ }^{5}$ served as the potential hosts. The inocula used were (a) viable resting spores, (b) zoospores from germinated resting spores, and (c) zoospores from epibiotic sporangia. Drops of these inocula in tap water were pipetted (1) into the clusters of immature leaves at the crowns of the plants and (2) onto the upper surfaces of the mature leaves. Suitable controls were maintained.

\footnotetext{
${ }^{3}$ See, however, Sparrow and Johns, Arch. Mikrobiol. 1965.

The epibiotic stage of $P$. heleocharidis is now known and is conspicuously different.-F.K. S.
} 
Infection of the immature leaves with either (a) or (b) types of inoculum was invariably obtained. On the other hand, attempts to inoculate more than 40 mature leaves by these inocula failed to result in a single infection. Two days following the inoculation of young leaves with zoospores, young epibiotic thalli could be observed microscopically. After $5-6$ days affected areas of the upper surface appeared pallid and yellowish and young endobiotic thalli could be demonstrated. Use of mature but ungerminated resting spores increased these time intervals by $48-60 \mathrm{hr}$, i.e., the time necessary for zoospore production.

When inoculum (c), i.e., zoospores from epibiotic sporangia, was used, it was prepared as follows: strips of epidermis bearing such sporangia were removed from young leaves, carefully washed, and placed in tap water on a slide until several epibiotic sporangia had discharged. After removing and discarding the epidermal strips, drops of the water containing these zoospores were pipetted into the young crowns as well as onto the mature leaves of uninfected Dulichium plants. As before, no infections occurred on the mature leaves, but within 2-3 days there were both epibiotic sporangia and young endobiotic thalli on the immature ones. These experiments clearly demonstrate that the zoospores from the epibiotic sporangia (1) are able

5 The Johns misting device is so cheap and effective that it should be more generally known. His description and diagram are therefore included. "A simple misting apparatus (Fig. B) was constructed based on controlled flow of air and water to atomizer nozzles (De Vilbiss \# 127). Rubber tubing connected these nozzles with an ordinary outlet for compressed air. Direct connection with the laboratory water supply was not feasible because of the marked inconstancy in water pressure. Therefore, a 10quart galvanized bucket was used as a reservoir, from which water, was siphoned through rubber tubing to the nozzles. Volume of flow was controlled with screw clamps. The bucket was connected with the water supply by means of $1 / 4$-inch copper tubing, and a float valve designed to maintain water level in the humidifier of a hot-air furnace (Skuttle Manfacturing Co.) was installed inside the bucket. This resulted in automatic maintenance of the water supply. Measurements of the relative humidity produced were in excess of $90 \%$ even in areas of the greenhouse $(30 \times 10 \mathrm{ft})$ not directly exposed to the mist."

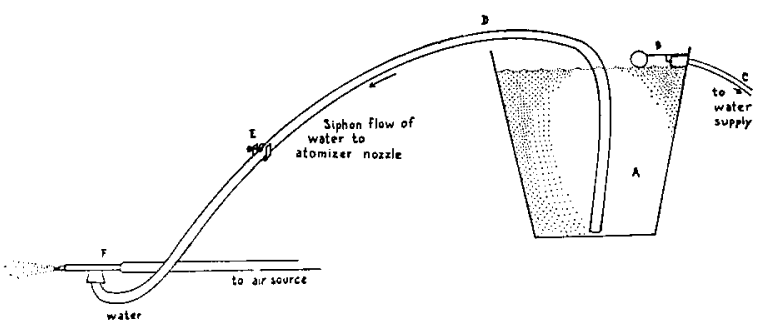

Fig. B. Misting Device. This apparatus includes a water reservoir (A) with an attached float valve (B) controlling flow of water through $1 / 4$ " copper tubing (C). Water from (A) siphoned through rubber tubing (D) equipped with screw clamp (E) to control volume of flow to atomizer nozzle (F) which is also connected with outlet for compressed air. to produce new epibiotic sporangia and (2) to give rise to the endobiotic phase of the fungus. Thus these spores may infect successively formed young leaves on the same host culm and, under appropriate conditions in nature, undoubtedly initiate new infections on other plants of Dulichium.

EcologY-Mode of infection in nature-It is apparent from the foregoing experiments that the initial infection of a young Dulichium plant depends upon the presence of a source of inoculum in the terminal cluster of young leaves, whether this be resting-spore zoospores or those from epibiotic sporangia. Both of these infective agents are probably operative in nature where transport of the inoculum to the plant is undoubtedly dependent upon the presence of free water.

The depth of water necessary for infection to occur is complicated by the nature of the development of the culms of Dulichium. The first-formed or juvenile leaves have short, almost scale-like blades which remain tightly appressed to the stem, the young culm strikingly resembling a shoot of asparagus. Infection has never been observed on such scales. Only after the culm has emerged $5 \mathrm{~cm}$ or more from the soil is the open terminal cluster of susceptible young leaves formed.

Field observations support the view that free water is necessary for the initiation of infection. In Smith's Bog, where the water level tends to drop during the latter part of the growing season, newly emergent culms which are above the waterline or in water of a depth to $3-4 \mathrm{~cm}$ remain free of infection. These are often surrounded by older, infected plants which developed at a time when the water level was higher in the bog. At the same time young culms growing in greater depths of water will show high percentages of infection. At Marl Bay on Douglas Lake and at nearby Blanchard Lake, where the stands of Dulichium extend above the seasonal high water level and the degree of slope of the basin is greater, an even sharper zonation is evident. At these sites the host plants growing above the high waterline were free of infection; scattered culms were infected in the littoral zone; and the percentage of infected plants in standing water ranged between $70-80 \%$. Perhaps the most striking evidence for influence of water level on infection is to be found at Mud Lake, Cheboygan Co., where there are extensive stands of Dulichium growing on the floating mat at the eastern margin, and in shallow water rooted on the bottom elsewhere. Those on the mat were free of infection despite the sodden nature of the substrate, whereas those rooted in shallow water were infected. Evidently the rise and fall of the floating mat, and non-inundation of the host culms, prevents infection.

Reinfection in nature-Although the original introduction of Physoderma dulichii to its host evidently depends upon the presence of standing water, this is not necessary for its subsequent development or for reinfection of successively formed leaves of a plant which is already infected. 


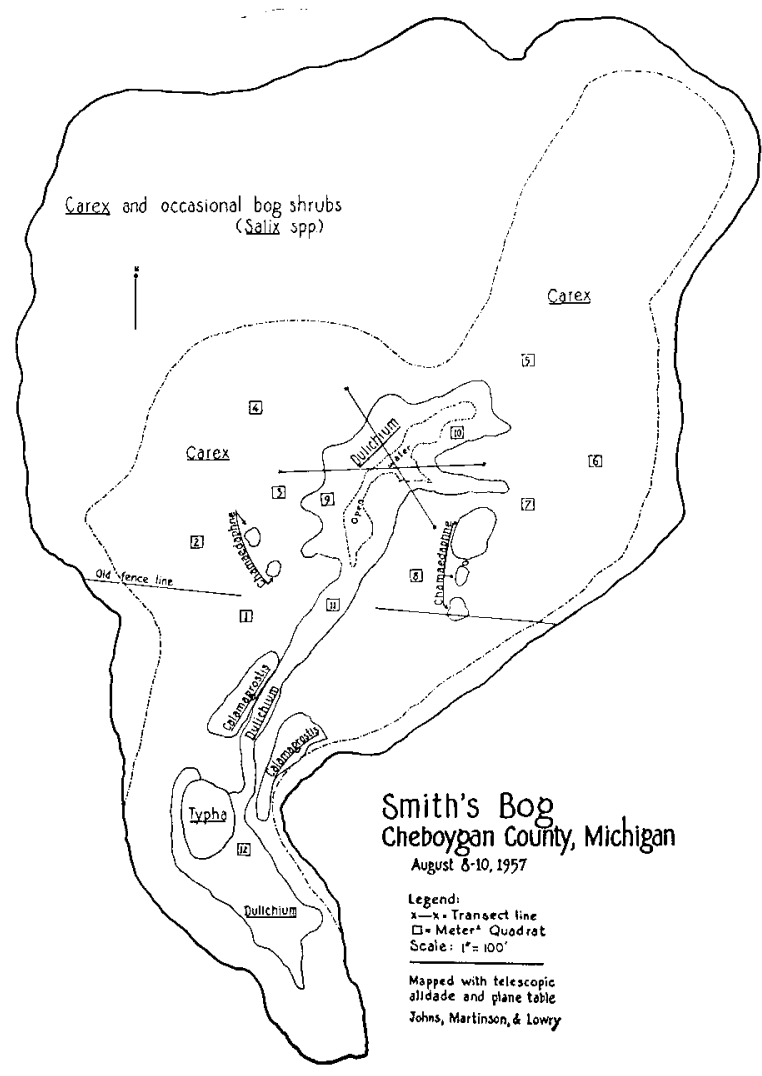

Fig. C. Map of Smith's Bog, Cheboygan Co., Michigan, showing principal vegetational zones and portions of transect lines and quadrats. Telescopic alidade and plane table by Johns, Martinson and M. Lowry.

In greenhouse inoculations, maintenance of high humidity with the previously described misting apparatus provided adequate moisture to obtain continuing infection of newly formed leaves from a single inoculation. Thus as many as 24 successive leaves may become infected over a period of 12 or more weeks. Interruption of the mist for $24 \mathrm{hr}$ did not affect reinfection by the organism, but after a 72-hr interruption, all leaves formed thereafter were free of the disease. From this, it seems likely that in nature rain, mist, and the condensation of dew abundant in situations where Dulichium is found provide adequate moisture to assure the development and propagation of the organism. It is probable that the agents of infection of all except the most basal leaves are zoospores from epibiotic sporangia which may proliferate great numbers of new sporangia and endobiotic thalli within successive leaves in the terminal cluster.

Host susceptibility and specificity-As previously indicated, under suitable conditions attempts to infect Dulichium plants from Smith's Bog have been uniformly successful. In addition, host plants from Nichol's Bog, Cheboygan County, Michigan, and from First Sister Lake, Washtenaw County, Michigan, both of which were free of infection in 1956, were brought into the greenhouse, and their young leaves were inoculated by the methods previously described. Every attempted inoculation resulted in typical infection.

On October 21, 1956, moist leaves bearing mature resting spores from Smith's Bog were placed in perforated polyethylene bags and tied to a stake in the midst of a population of Dulichium growing in this area which had been free of Physoderma dulichii in the 1956 growing season. On June 14, 1957, infection was observed around the whole periphery of the bog, and $50-60 \%$ of the host plants growing in standing water were infected. The organism had spread too rapidly, however, for any pattern of dissemination to be evident.

These preliminary data suggest that Dulichium is quite susceptible to infection by Physoderma dulichii. No natural resistance to the fungus has been encountered either in populations or in individuals. Its wide-spread occurrence in Eastern North America, to be discussed, also supports this conclusion.

Characteristics of the type locality-Smith's Bog (Fig. C) is a small senescent bog on the margin between Munro and Burt Townships in Cheboygan County, Michigan. It is surrounded by a mixed growth of aspens except at the southern end, where lowland forest species predominate. The mat, which is well grounded and extensive in size by comparison with the central bog pool, is open except marginally and in the northwest area where a considerable growth of bog shrubs dominated by Salix sp. has developed. The dominant plant on the mat is Carex lasiocarpa with Dulichium arundinaceum next in order of frequency, but this association is occasionally interrupted by areas in which Calamogrostis canadensis, Chamaedaphne calyculata, Rhynchospora fusca, or Typha latifolia may be the dominant plant.

The bog pool is shallow, the greatest measured depth below the marginal turf of the Carex mat being $0.8 \mathrm{~m}$, and the bottom, which is relatively firm, might best be described as muck, sensu Webster, "impure or decayed peat or black swamp earth ..." This depression includes an area of irregular outline in the approximate center of the bog that narrows to form a meandering channel which widens somewhat to form an oblong secondary basin near the southern end of the bog. The pool is clearly divided into two vegetstive zones. The first of these is an area of more or less open water which is limited to the central region of the northern basin. The dominant plant here is Glyceria borealis, with scattered individuals of Nuphar variegatum, Hypericum boreale, forma callitrichoides, and a few other species. Surrounding the open water and occupying all of the channel and the southern basin is the second of the vegetative zones, in which Dulichium is dominant. The only other species which occur with any frequency in this zone are Eleocharis palustris var. palustris, and, in the southern basin, Sparganium minimum. A list of the plants in these several zones during the years 1956 and 1957 was recorded. 
The recent history of Smith's Bog-A significant body of knowledge concerning the bog has accumulated during the last half-century chiefly through the efforts of F. C. Gates (1942) and of his students, especially Woollett, Dean and Coburn (1925). Through these studies and the observations of the writer in 1956 and 1957, it is possible to trace the recent development of the habitat and of its flourishing population of Dulichium. The following historical data are from Woollett, Dean and Coburn (1925).

In 1911 the bog pool was at least four times its present size, and Dulichium was present only as a constituent of the Carex lasiocarpa association on the mat. The mat floated, rising and falling with changes in water level. Around the margin of the bog was a shrub zone dominated by Chamaedaphne calyculata and Nemopanthus mucronata.

A series of two fires in 1914 and 1916 markedly affected the area. The first of these was limited chiefly to the surrounding uplands, but in 1916 the bog itself was burned, and the marginal Chamaedaphne and Nemopanthus association was virtually eliminated. Also, a portion of the mat became grounded in 1916. In subsequent years there was a rapid extension of the Carex lasiocarpa, with Nuphar variegatum, growing attached to the margin of the mat, as the pioneer of the open water of the pool.

By 1924 a considerable portion of the mat had become grounded, although "where there is considerable water, the mat is still of a quaking character." The pool was hardly larger than its present size, and Nuphar had become established in the pool itself, rooted in the bottom. The peripheral Dulichium zone had not become established, but this sedge was the most frequent species, after Carex lasiocarpa, on the mat. The few patches of Chamaedaphne and Nemopanthus which had survived the fire were said to be "spreading rapidly and new ones are appearing and developing rapidly."

Woollett, Dean and Coburn ended their summary with the following statement: "The bog as a whole is rapidly becoming drier and it is predicted that in ten to twenty years the water will entirely disappear, leaving a dry Carex meadow."

"This meadow will be invaded by the Chamaedaphne, Myrica, Salix, and high-bog thicketassociations and eventually the lowland forest at the southern end may extend well into the open bog."

It is apparent that their predictions have not been justified by the intervening 34 years. The bog pool is scarcely smaller, and the water has certainly not disappeared. Although Salix species are present, neither Myrica nor Nemopanthus was found on the mat itself, and the scattered clumps of Chamaedaphne do not appear to have increased in number or area since 1924. Indeed, many of them are dead or dying. Further, the flora of the bog shows little qualitative change.

The two most striking developments since 1924 have been the complete grounding of the bog and the establishment of the Dulichium association in the marginal and shallower areas of the pool.

Because the mat is firmly grounded, it is frequently inundated due to seasonal and sporadic rises in water level, which tend to be high during the early part of the year due to winter precipitation and to drop as the growing season progresses. On March 30, 1957, the mat was covered to a depth of $15-28 \mathrm{~cm}$; this varied from $2-14 \mathrm{~cm}$ on June 20 of that year; by July 12 the surface of the mat was exposed up to the margin of the pool. However, local rains during the latter part of July had raised the level to $0-8 \mathrm{~cm}$ by August 2 . On August 21 the level had again dropped to the extent that a portion of the mud flat in the Dulichium association was exposed.

It is probable that the grounding of the mat was a necessary prerequisite for the advance of Dulichium into the pool. This sedge propagates itself chiefly by means of stout rhizomes; although abundant seed are produced in the bog, germinating seedlings have not been observed. It seems likely that the joining of the mat with the bottom of the shallow pool permitted the invasion of the area by Dulichium rhizomes from the mat. The reasons for the accelerated and dominating growth of Dulichium and the failure of C. lasiocarpa to keep pace and maintain its dominance are not clear, although this situation may be related to the marked fluctuations in water level. Whatever the basis for its dominance, Dulichium is highly successful there, and this zone is also the center of a highly successful epidemic of Physoderma dulichii.

Physoderma dulichii in Smith's Bog-During the early part of the summer, infected Dulichium plants are evident both on the Carex mat and in the pool. As the season progresses the relative number of infections on the mat drops off sharply, while the frequency in the pool remains high. Since new culms of the host are produced continuously throughout the growing season and the older plants die as the season advances, there appeared to be a drop in infection on the mat which was associated with the progression of the summer and the consequent fall of the water level. To confirm this a number of random, square-meter quadrats on the mat were examined to determine the total number of host culms present and the number which were infected with $P$. dulichii. Dead individuals were counted as well as living ones, and these data are plotted separately. All instances in which infection was doubtful, including all dead host plants, were subjected to microscopic examination. It should be noted that the latter were in an advanced state of decomposition with many of the leaves missing; it seems likely that the percentage infection indicated for the older dead plants is conservative. For purposes of comparison, several similar quadrats were surveyed in the Dulichium zone, but in these only the erect, living culms were examined. This study was made on 
Tarte 1. Percentage infection by Physoderma in living and dead Dulichium on the Carex mat

\begin{tabular}{|c|c|c|c|c|c|c|c|c|c|}
\hline & 1 & 2 & 3 & 4 & $\begin{array}{c}\text { Quadrat } \\
\quad 5\end{array}$ & 6 & 7 & 8 & Total \\
\hline \multicolumn{10}{|l|}{ Living Plants } \\
\hline Total Number & 131 & 138 & 153 & 129 & 143 & 131 & 142 & 148 & 1115 \\
\hline Number infected & 0 & 0 & 0 & 0 & 2 & 0 & 1 & 0 & 3 \\
\hline Percentage infected & 0 & 0 & 0 & 0 & 1.4 & 0 & 0.7 & 0 & 0.27 \\
\hline \multicolumn{10}{|l|}{ Dead Plants } \\
\hline Total Number & 24 & 27 & 19 & 11 & 31 & 17 & 19 & 21 & 169 \\
\hline Number infected & 3 & 10 & 5 & 3 & 16 & 5 & 7 & 8 & 57 \\
\hline Percentage infected & 12.5 & 37.1 & 26.3 & 27.2 & 51.6 & 29.4 & 35.8 & 38.1 & 33.7 \\
\hline \multicolumn{10}{|l|}{ Living and Dead Plants } \\
\hline Total Number & 155 & 165 & 172 & 140 & 174 & 148 & 161 & 169 & 1284 \\
\hline Number infected & 3 & 10 & 5 & 3 & 18 & 5 & 8 & 8 & 60 \\
\hline Percentage infected & 1.9 & 6.66 & 2.9 & 2.1 & 10.3 & 3.3 & 4.9 & 4.7 & 4.67 \\
\hline
\end{tabular}

TABцE 2. Percentage infection of Dulichium in the pool

\begin{tabular}{lccccc}
\hline \hline & & Quadrat & & \\
& 9 & 10 & 11 & & Total \\
\hline Total Number & 601 & 587 & 614 & 547 & 2349 \\
Number Infected & 474 & 430 & 529 & 449 & 1882 \\
Percentage Infected & 78.8 & 73.4 & 86.1 & 81.1 & 80.1 \\
\hline
\end{tabular}

August 27 and 28,1956 , and the data are presented in Table 1.

Despite the relatively small populations of older (dead) plants sampled, it is clear that percentage infection on the mat decreases with the advance of the growing season. The data from the Dulichium zone suggest that this is not true in the margin of the pool. These observations suggest that the observed pattern of infection is directly correlated with the water level in the bog.

The quadrats ${ }^{6}$ in the margin of the pool (Table 2) also illustrate how many stems of Dulichium can be crowded into an area of one square meter. An enumeration of all other plants found in these four square meters follows: 7 Eleocharis palustris var. palustris, 4 Hypericum boreale var. callitrichoides, 3 Glyceria boreale, 1 Eleocharis compressa and 1 Sparganium minimum.

GeographiCal Distribution-Shortly after the discovery of Physoderma dulichii, a packet of infected Dulichium was examined. Several years earlier it had been sent to Dr. F. K. Sparrow, Jr. by Prof. H. S. Jackson of the University of Toronto. It had been collected at Diamond Lake in the Timagami Forest Reservation (Nipissing Co., Ontario) in 1955 and was labelled "Olpidium (?)" (9102 [TRTC]). It proved to be infected with $P$. dulichii. Jackson had observed advanced stages of the organism in which the rhizomycelial ele-

\footnotetext{
- In addition to the random meter quadrats, a series of 559 contiguous quadrats $10 \mathrm{~cm}^{2}$ were surveyed along two transects which intersected in the center of the bog pool and which included representative areas of the pool and bog mat (Fig. C). These data are presented in the thesis.
}

ments are not apparent and had made the reasonable error of assuming the resting spores to be those of the holocarpic chytrid genus, Olpidium. This early suggestion that the fungus might be widely distributed, together with the ease with which it could be identified, led to a search by way of herbarium material for other sites.

Collections of Dulichium in 21 herbaria in the United States and Canada were examined. These included all herbaria in this country which contain in excess of one million specimens (Smith, 1956) and most other major collections within the distribution range of the host. As a result of this examination, 72 sites $^{7}$ for Physoderma dulichii are known, confined to 13 states in the northeastern United States and three eastern provinces of Canada, namely, Maine, Massachusetts, New Hampshire, Vermont, Rhode Island, New York, New Jersey, Pennsylvania, Delaware, Indiana, Michigan, Minnesota, Wisconsin, Nova Scotia, Quebec, Ontario.

It is evident that the distribution of an obligate parasitic organism is dependent upon, and must be correlated with, the range of its host. Dulichium arundinaceum occurs throughout the northeastern United States and northward in Canada as far as Newfoundland. In the northern part of its range, it extends westward to British Columbia, Washington, Oregon, and California, and it is found as far south as central peninsular Florida and east-central

${ }^{7}$ These are eited specifically in the thesis which may be consulted. The author thanks Dr. R. A. Paterson, Dr. C. E. Wood, Dr. M. IS. Bigelow, Dr. W. J. Koch and J. A. Martinson for their assistance. 
Texas, although the inclusion of the latter state seems to be based on a single site (Robertson Co., F. A. Barkely 13732 [TEX, TAES, MO, NY, F', MICH]). Examination of collections suggests that there is a decrease in the frequency of occurrence of this sedge southward from the Great Lakes and Middle Atlantic states. This opinion was supported by Dr. J. A. Steyermark (personal communication), whose collections of Dulichium from the lower middle west are the most extensive that have been examined. Dr. Steyermark also stated that in Missouri and the adjacent Ozark regions, the host is limited to areas such as isolated sinkhole ponds.

In the examination of herbaria, special attention was given to Dulichium collected outside North Eastern America. In herbaria in the South (NCU, DUKE), the Southwest (TEX, TAES), the Central States (MO), and the West (UC), sheets of infected specimens may frequently be found, but they are collections of the host plant made in the northeastern United States. Other large herbaria (GH, US, NY, PH, PENN, F) have contained significant southern and western collections and these are free of infection. If not convincing, such negative data are at least provocative. Although further study will undoubtedly extend the present limits of the range of Physoderma dulichii, several factors suggest that the limited pattern of distribution shown here, i.e. Great Lakes, St. Lawrence River Valley and northern half of the Atlantic Coastal Plain, is a real and valid one. These factors include (1) the frequency of infected host collections from Northeastern North America, (2) the marked pattern of distribution exhibited by these collections, (3) the large number of representative collections of the host which were examined, and (4) the lack of a single infected specimen from southern and western states.

\section{LITERATURE CITED}

Gates, F. C. 1942. The bogs of northern lower Michigan. Ecol. Monogr. 12: 213-254.

Johns, R. M. 1957. A new species of Physoderma on Dulichium. Mycologia 49: 298-299.

Jones, F. R., and C. Drechsler. 1920. Crownwart of alfalfa caused by Urophlyctis alfalfae. J. Agric. Res. 20: $295-324$.

Kreteger, 1896. Fungi saxonici exsiccati. Hedwigia 35: $142-145$.

Schroeter, J. 1886. Die Pilze Schlesiens. In Cohn, Kryptogamenfl. Schlesiens 3: 1-814. 1885-1889.

Sмiтu, A. C. 1956. Herbaria of the United States. A.I.B.S. Bull. 6: 12-15.

Woollett, E., D. Dean, and H. Coburn. 1925. An ecological study of Smith's Bog, Cheboygan County, Michigan. Papers Mich. Acad. Sci. Arts and Let. 5: 201-210. 